\title{
Introducing World Englishes Accents to Elementary School Learners
}

\author{
Panisara Sriwang* \\ Denchai Prabjandee \\ Punwalai Kewara \\ Faculty of Education, Burapha University, 169 LongHad Bangsaen RD, Chonburi 20131, Thailand
}

\begin{abstract}
Exposing learners to various accents is important in the age of globalization since it prepares learners to communicate with sociolinguistic reality outside the classroom. This research aimed to investigate the effects of teaching World Englishes accents on learners' intelligibility and attitudes towards learning English. The study was conducted at a private elementary school in Chonburi province, Thailand. The participants were 34 elementary school learners, who enrolled in the English club. The study used a mixed-methods approach to guide the data collection and analysis. Three World Englishes accents were included in the instruction (English, Filipino and Chinese) because they were the accents available outside the classrooms. After the instruction, the learners were interviewed to explore their attitudes toward learning English. The findings indicated that the learners' intelligibility score after receiving the accent instruction was significantly higher than before the instruction. The interview also indicated the learners reported having positive attitudes toward learning English and the World Englishes accents.
\end{abstract}

Keywords: World Englishes accents, elementary school learners

DOI: $10.7176 / \mathrm{JEP} / 11-33-19$

Publication date: November $30^{\text {th }} 2020$

\section{Background of the Study}

From the $17^{\text {th }}$ century onwards, the English language began to spread globally due to the power of the British empire (Galloway \& Rose, 2015). The global spread of English could be explained by various reasons. Jenkins (2015) explained why English spread all over the world in terms of waves of immigration, where English users immigrated to new territories. Also, Galloway and Rose (2015) further discussed that English spread through four channels: 1) settler colonization, 2) slavery, 3) trade and exploitation colonies, and 4) globalization.

Based on the global spread of English, it is safe to say that the status of English has truly become a global language being the official language of the international and multinational industries, and the language of Internet (Crystal, 2003). It is also a truly global language since approximately 1.5 billion people across the planet speak English, representing 20 English users worldwide (Crystal, 2003). Of these speakers, Crystal (2003) estimated that 375 million people are native English speakers, and 1.2 billion people are non-native English speakers. The estimation in 2003 was conservative, and it is argued that the number of English users has been increasing drastically since then (Galloway \& Rose, 2015). When English users become more diverse, the English language is spoken in various accents from different parts of the world (Sung, 2016).

In addition, the spread of English extends to the ASEAN region, where it is the home of great ethnic, cultural, political, and economic diversity. In the policy, English is designated as the sole working language of the region (Kirkpatrick, 2010). In reality, it has a different statuses and performs different roles in each ASEAN member states (Low \& Ran, 2018). As a result, it is likely that ASEAN people are required to learn their respective national language and English. This combination of the learning of English is along with the learning of a national language, which can be a national lingua franca. In this region, it is likely that English is also spoken in various accents.

Moreover, based on the spread of English, several researchers have examined linguistic features of Englishes, or "World Englishes." According to Krachu (1985), World Englishes is a term for emerging localized or indigenized varieties of English, especially varieties that have developed in territories influenced by the United Kingdom or the United States. Originally, the study of World Englishes attempts to codify varieties of English used in diverse sociolinguistic contexts globally and analyzing how sociolinguistic histories, multicultural backgrounds and contexts of function influence the use of English in different regions of the world (Galloway \& Rose, 2014). The field of World Englishes has proliferated and many English Language Teaching (ELT) researchers call for the need to incorporate World Englishes in the classroom (Matsuda, 2003; Sung, 2016). It is this line of research that we want to undertake.

\subsection{Statement of the problems}

The fact that there are World Englishes out there makes it relevant to pedagogy (Sung, 2016). Learners should be exposed to different English accents in order to prepare them for the sociolinguistic reality outside the classrooms (Prabjandee, 2020; Sung, 2006). Many researchers have attempted to implement World Englishes in the 
classrooms (e.g., Ates, Eslami, \& Wright, 2015; Baik \& Shim, 2002; Eslami, Moody, \&Pashmforoosh, 2019; Solmaz, 2020); however, it is observed that most studies focused on undergraduate learners. While promising empirical evidence of the positive effects on these groups were reported, it has limited understanding whether World Englishes could be implemented with younger learners, such as those in elementary schools. As a result, there should be more research on how to incorporate World Englishes into classrooms, especially for elementary school learners. The integration of World Englishes in the classroom is beneficial for the learners because it may help learners become aware of the diverse nature of English and it prepares them for the messy world of English users (Prabjandee, 2020).

Additionally, even though English has been taught in Thailand for more than a century, yet prior research has demonstrated that many English teachers reported using only the native English norm in the classrooms (Phongsirikul, 2017; Prabjandee, 2020). For example, Phongsirikul (2017) demonstrated that many Thai teachers learned English in the $20^{\text {th }}$ century, and they have to teach English in the $21^{\text {st }}$ century. This means that the English language they learned has already been changed its role and statuses. As a result, exposing learners to native speaker English accents only is problematic because it does not prepare learners for the messy world of English users, where they have to interact with more than native speakers, and it may create false perception that English has a single form (Matsuda, 2003; Prabjandee, 2020). Based on these problems, it is important to start raising awareness for younger learners to understand the plurientricity of English and to have positive attitudes toward learning English.

\section{The Present Study}

2.1 Research questions

This study attempts to answer to the following research questions:

1. What are the effects of teaching World Englishes accents on learners' intelligibility?

2. What are the effects of teaching World Englishes accents on learners' attitudes toward learning English?

\subsection{Context of the study}

This study was conducted at a private elementary school in Chon Buri province, located in the eastern part of Thailand. In this school, at the time of data collection, there were 2,630 learners who were studying from the levels of kindergarten to Grade 12. The school used Thai and English as the medium of teaching, while Chinese was an optional subject. The participants in this study were purposively selected from one of the school clubs called English club, which was an alternative class for learners who could choose to participate based on their interests. The club was run at the last period on Thursdays. It took fifty minutes. This club hour was a part of school curriculum. The objectives of the club were as follows: 1) Learners could read aloud the vocabulary correctly. 2) Learners could understand the meaning of each word. 3) The learners could express their attitude towards learning vocabulary. There were 34 club members in the club.

\subsection{Research design}

This study employed a mixed-method research with an explanatory sequential design to investigate the effects of teaching World Englishes accents on learners' intelligibility and attitudes toward learning English. According to Creswell (2012), the explanatory sequential design places a priority to quantitative data collection, followed by qualitative data collection to explain the results in the quantitative phase. Mixed-methods research was used because it helped explain the potential reasons of the effects. Based on the design, starting with the participants performing a pretest before giving the instruction. Next, three types of Word Englishes accents were taught (British, Chinese, and Filipino accents). The vocabulary consisted of four categories: 1) clothes, 2) food, 3) animals, 4) family. Finally, after the treatment process, the learners performed the post-test. For the next step, the learners were asked to complete a questionnaire in order to explore their attitudes toward learning English.

\subsection{Participants}

The population was 198 Grade 4 learners at a private elementary school, which was situated in the eastern part of Thailand. Out of 198 learners, the participants were 34 learners, selected by using the purposive sampling technique. Based on the participants' sex, 18 learners were male, and 16 ones were female. These learners were the members of English club, which was handled following the school syllabus as the extra curriculum or activity. All club activities focused on learning English for communication and getting well-prepared for further education.

\subsection{Instructional framework}

The framework of teaching procedures in the lesson plans used in this research study was designed in five steps as follows: 
2.5.1. Introduction of World Englishes accents. In this step, the learners were asked to listen actively to the vocabulary pronounced with three different accents (British, Filipinno, and Chinese). The various accents were blinded, so the learners were not aware that the accents were different. The goal of this step was to expose the learners to how each word was pronounced by speakers from different sociocultural backgrounds.

2.5.2. Discussion. In this step, the learners were prompted to share their opinions about the vocabulary they listened to in this first session. The learners were encouraged to express their opinions towards different accents on the basis of following questions: What words did they hear? What was the accent they hear like? Where could they hear this accent? Which accent was the easiest to understand? The discussion in this step aimed to elicit prior assumptions about the accents.

2.5.3. Accent Analysis. In this step, the learners worked collaboratively to analyze and differentiate the accents they heard. They were encouraged to focus on sounds and compared the sounds across the three accents. They were asked to use their own words to describe the accents.

2.5.4. Practice. In this step, the learners practiced how to pronounce each accent. They practiced one by one. The goal of this practice was to familiarize the learners with how each word is pronounced.

2.5.5. Debriefing For this final step, the learners listened to the words again, and the researcher's explanation of various accents. Finally, they reviewed the lesson by studying each answer.

\subsection{Research instruments}

2.6.1 Learner's intelligibility test. The test was created by selecting vocabulary from the textbook currently used at the school in the English subject. The textbook is matched with Thailand's Basic Education Core Curriculum in B.E. 2551. The test content derived from the lessons in the textbook were classified into four categories:1) clothe, 2) food, 3) animals, and 4) family. There were 12 items in the test. In each item, one accent was randomly selected from the pool (British, Fililipinno, Chinese) to read the vocabulary. Before and after receiving the World Englishes instruction, the learners were requested to take the learner's intelligibility test in order to check their intelligibility. To complete the test, the learners listened to the accent and wrote down the words they heard down in the exam paper. One point was given when a word was written correctly. The learner's intelligibility test was validated by three experts using the Index of Item Objective Congruence (IOC). The items with IOC value of $\geq 0.5$ were acceptable.

2.6.2 Questionnaire. The questionnaire was developed in order to measure the learners' attitudes toward learning English. The questionnaire consisted of 12 questions which were translated into Thai to avoid misunderstanding. Four scales were applied in this questionnaire: Never, Sometimes, Often, and Regularly.

Since the questionnaire were developed, the validity and the reliability analysis were performed to validate both research instruments. Three experts were involved to examine the validity and the translation. The Index of Item Objective Congruence (IOC) statistical analysis was used for this step. The items with IOC value of $\geq 0.5$ were acceptable. Then, the questionnaire was piloted to examine the reliability rate. The reliability analysis of the questionnaire was performed by running the Coefficient Alpha of Cronbach $(\alpha)$. The results showed that the questionnaire's reliability was .941 .

\subsection{Ethical considerations}

For this research, ethical considerations were followed strictly. The ethical considerations in this study included informed consent, voluntary participation, no harm, confidentiality. All participants were fully informed about the research purpose evaluation, activities, and interviews being conducted in order to make decision as to whether they would participate in the study or not. The school director as the learners' main caretaker was also informed. Moreover, all participants who took part in this study were free from any enforcement and they could withdraw their participation at any time without any negative impact on their education. In addition, both physical and psychological harms were considered not definitely setting to every participant. Lastly, any identifying information of the participants was not accessed by anyone but the researcher.

\section{Findings}

3.1. Research Question 1: What are the effects of teaching World Englishes accents on learners' intelligibility? To answer the above question, the data from the learner's intelligibility test were used. To elaborate, 34 learners were asked to take two sets of learner's intelligibility tests before and after learning about World Englishes accents. In this section, the data from the test will be presented first. The data were analyzed by using descriptive statistics and Dependent sample t-test. The results of descriptive statistics are presented in Table 1.

Table 1Descriptive statistics of pre-test and post-test

\begin{tabular}{llll}
\hline & $\mathrm{N}$ & Mean & SD \\
\hline Pre & 34 & 5.14 & 3.28 \\
Post & 34 & 8.61 & 3.22 \\
\hline
\end{tabular}


As shown in Table 1, the participants' pre-test mean score was $5.14(S D=3.28)$ and post-test mean score was $8.61(S D=3.22)$. It is obvious that the post-test mean score is higher than the pre-test mean score.

A correlation analysis was performed in order to investigate the potential relationship between the pre-test and the post-test. The findings revealed that the score of both tests were highly correlated as presented in Table 2 $($ Correlation $=.81)$.

Table 2 Paired Samples Correlations

\begin{tabular}{llll}
\hline & $\mathrm{N}$ & Correlation & Sig \\
\hline Pair 1 pre \& post & 34 & .81 & .000 \\
\hline
\end{tabular}

In the present study, English accents (pre-test and post-test) were assigned to the participants before and after the treatment of English accents. The aim of using pre-test and post-test was to check the learners' intelligibility and their improvement. The final draft of the test contained twelve items divided into one section: Listening and write the vocabulary words. After the test was taken by the target sample, paired sample statistics (t-test) was used to calculate and computer the mean of one group pre-test and post-test. With analysis using this method we can determine whether there was significant difference between the pre-test and post-test results. The following table shows the results for the pre-test and post-test results. The following table shows the results for the pre-test and post-test. Table 3 show the mean scores compared between pre-test and post-test as well as determination if there was a statistically significant (sig). difference.

Table 3 T-test Results of Pre-test and Post-test $(\mathrm{N}=34)$

\begin{tabular}{llllll}
\hline \multicolumn{2}{l}{ Paired Samples Statistics } & \multicolumn{5}{l}{ Paired Samples Test } \\
\hline $\begin{array}{l}\text { Overall } \\
\text { average score }\end{array}$ & $\begin{array}{l}\text { Mean } \\
\text { total 12 }\end{array}$ & S.D. & Mean & t & Sig. (one-tail) \\
\hline Pre-test & 5.14 & 3.28 & -3.47 & -10.10 & .00 \\
& & & & \\
& & & & \\
\hline Post-test & 8.61 & 3.22 & & \\
\hline
\end{tabular}

As show in Table 3, the results indicate that the overall pre-test mean was 5.14 while the post-test mean was 8.61 out of a total of 12 marks $(M=-3.47)$. According to statistical data analysis and results, there is a significant difference in value between pre-test and post-test at the level of .05 ( $\mathrm{sig}=0.00, \mathrm{t}=-10.10)$. The increased value could be interpreted as an improvement and progression of the participants in English accent intelligibility.

Apart from the quantitative data, this study also collected qualitative data from the researcher's reflection to explore the effects of teaching World Englishes accents on learner's intelligibility. Generally, it was found that learners expressed a willingness to learn about various accents, especially when they heard Filipino and Chinese accents. This section presents the researcher's reflection from each category first, followed by a conclusion.

3.2 Research Question 2: What are the effects of teaching World Englishes accents on learners'attitudes toward learning English?

To analyze the participants' attitudes towards learning World English accents, the adapted four-scale design: 1 = Never, 2 = Sometimes, 3 = Often, and 4 = Regular was applied. Thirty-four participants were requested to complete the questionnaire. After that the data were analyzed statistically. The findings are presented in Table 4. 
Table 4 Showing the mean of the student attitude survey question

\begin{tabular}{|c|c|c|c|}
\hline Item & Mean & SD. & $\begin{array}{l}\text { Interpret } \\
\text { results }\end{array}$ \\
\hline 1. I like to learn English every day. & 3.61 & .55 & regularly \\
\hline 2. I was energetic when I arrived at the English class. & 2.91 & .83 & often \\
\hline 3. I like to answer questions when attending an English class. & 2.85 & .92 & often \\
\hline $\begin{array}{l}\text { 4. I love listening to English vocabulary with different } \\
\text { accents. }\end{array}$ & 3.44 & .99 & regularly \\
\hline $\begin{array}{l}\text { 5. I want to have foreign friends to practice speaking } \\
\text { English. }\end{array}$ & 2.23 & .98 & sometimes \\
\hline 6. I paid attention and studied while the teacher taught. & 3.05 & .64 & often \\
\hline 7. I memorized English words. & 3.82 & .52 & regularly \\
\hline 8. I participated in group activities and had fun. & 3.41 & .74 & regularly \\
\hline $\begin{array}{l}\text { 9. I pronounce vocabulary on CDs and on various } \\
\text { media. }\end{array}$ & 2.52 & .99 & often \\
\hline $\begin{array}{l}\text { 10. I use the knowledge from English language class } \\
\text { to use in daily life. }\end{array}$ & 3.08 & .83 & often \\
\hline $\begin{array}{l}\text { 11. I like to listen to the English accent of different } \\
\text { English vocabulary. }\end{array}$ & 3.23 & .96 & regularly \\
\hline $\begin{array}{l}\text { 12. I have more knowledge of vocabulary from } \\
\text { English pronunciation. }\end{array}$ & 3.08 & .85 & often \\
\hline All items & 3.08 & .43 & often \\
\hline
\end{tabular}

For data analysis, the criteria of the interpreting scales as follows: $1-1.75=$ "Never," $1.76-2.50=$ "Sometimes," $2.50-3.25=$ "Often," and 3.26-4.0 = "Regularly." Based on the results of this analysis, the item no. 7 "I memorized English words." gained the highest level $(\mathrm{M}=3.82, \mathrm{SD}=.52)$, while the lowest level belonged to item no. 5, "I want to have foreign friends to practice speaking English." $(\mathrm{M}=2.23, \mathrm{SD}=.98$. For all items, the overall mean of the perceived value was $3.08(S D=.43)$ which indicates that the opinions about preferences in a variety of vocabulary accents obtain the 'often' level.

\section{Discussion}

The effects of introducing World English accents for elementary school learners was clear in this study. Learners' intelligibility test score after receiving the instruction was significantly higher than before the instruction. Also, learners reported positive attitudes toward learning English. The findings in this study contributed to the current literature on incorporating World Englishes in the classrooms (Ates et al, 2015; Baik \& Shim, 2002; Eslami et al., 2019; Solmaz, 2020).

This study focuses on examining the effects on attitudes of Thai learners towards a wide range of English pronunciation with various accents. According to the research findings, it was found that the majority of the participants had more positive attitudes towards learning English vocabulary with different accents. The data showed that the use of various accents of vocabulary pronunciation caused learning activities more interesting to the learners. Accent comparison led learners to be more interested in studying and have supportive attitudes towards the English classes and brought about better outcomes of vocabulary tests.

Moreover, the results of the questionnaire data showed that the learners had positive attitudes towards learning English. At the elementary level, the use of engaging teaching activities for the learners should be widespread in classroom management and teaching. As mentioned, this proof can enlighten everyone who teaches English in order to assist the teacher to design the teaching activities for the learners to make them well motivated to learn English.

With regard to the previous studies, Matsuda (2003) claimed that proper teaching procedures can enhance learners' positive attitudes and help the learners learn the language easily. With insufficient exposure to the English language can confuse learners and force them to abandon learning. The supportive attitudes towards learning have a great impact on learners' gaining language skills. Gardner (1985) stated that a learner, with a positive attitude towards language, culture and towards learning a foreign language, will be a successful language learner. This means that positive attitudes encourage learners to feel more like to interact and learn foreign language. As a result, all language learners should be prepared for imminent engagements with speakers of varieties of English that contradicts their own (Jenkins, 2000).

In addition, a variety of English accents in teaching process assists learners to perceive vocabulary knowledge together with its correct pronunciation and different accents. Based on the framework named English 
Accent (Stroll, 2002), different accents were introduced in pronunciation classes with group-based activity in discussion process. This supported the learners' positive attitudes towards learning vocabulary and pronunciation, and led to better perception of vocabulary competence.

These findings also proved that open atmosphere in the classroom, which the learners could express their opinions during group-based activities, causes helpful motivation in learning. With different accents introduced in class, learners had a good opportunity to challenge their peers to guess the specific accent, to imitate the different accents. The learners can learn the right or better pronunciation through comparative learning procedures. Moreover, it is said that since English is the global language, new varieties of English are constantly being developed with their own unique identities (Crystal, 2003). As a result, leaning English through the realworld setting enhances learners to expose themselves to World Englishes.

Even though this research has gained it purpose, there were some limitations. First, this research was conducted only on a small size of population. Therefore, in order to generalize these findings to a larger group, the study should have been involved with more participants. Second, for quantitative data, both vocabulary tests and questionnaire were objective questions, so the data were still limited. Additional opened questions such as an interview questions should have been also introduced. Lastly, only one voice from each accent was introduced, more sounds from different persons should have been added.

\section{Implications}

This present research offers the empirical proof for the effects on attitude towards learning a variety of English accents. This study provides the implications as follows. For pedagogical field, the results suggest that in vocabulary or pronunciation classes, the educators or instructors should be aware of the proper learning activities, teaching aid materials, and practical use in real life. This is to help learners retain their knowledge and apply in the real world. For communicative area, learning different accents in vocabulary pronunciation can support the learners to interact or respond to the conversation in different contexts or settings. This causes the learners to have more confidence to communicate with people in English in various scenes.

\section{Recommendations for Future Research}

These results reveal that the impact on the attitudes towards learning a variety of English accents. The recommendations for further research studies are presented. First, this research was conducted only on a small size of population, who were only 34 Grade 4 learners. Therefore, in order to generalize these findings to a larger group, the study should be concluded with a wide range participants; more numbers of learners from more schools should be added. In this study, both vocabulary tests and questionnaire were objective questions. Additional opened questions such as an interview questions should be also conducted. More sounds from different persons should be added, including more different accents such as American, Thai, or Australian accents. For further research studies, different English skills e.g. speaking and listening should be performed.

\section{References}

Creswell, J. W. (2012). Educational research: Planning, conducting, and evaluating quantitative and qualitative research. Pheonix: Pearson.

Crystal, D. (2007). English as a global language. Cambridge: Cambridge University Press.

Galloway, N., \& Rose, H. (2015). Introducing global Englishes. London: Routledge.

Jenkins, J. (2015). Global Englishes: A resource for learners. Oxford: Oxford. University Press.

Kirkpatrick, A. (2010). English as a lingua franca in ASEAN: A multilingual model. Hong Kong: Hong Kong University Press.

Kachru, B. B. (1985). Standards, codification and sociolinguistic realism: The English language in the outer circle. In R. Quirk and H. G. Widdowson (Eds.), English in the world: Teaching and learning the language and literatures (pp. 11-30). Cambridge: Cambridge University Press

Low, E. L., \& Ran, A. (2018). The Spread of English in ASEAN: Policies and Issues. RELC, 49(2), 131-148

Matsuda, A. (2003). Incorporating world Englishes in teaching English as an international language. TESOL Quarterly, 37(4), 719-729

Prabjandee, D. (2020) Teacher professional development to implement Global Englishes language teaching. Asian Englishes, 22(1), 52-67.

Sung, C. C. M. (2016). Exposure to multiple accents of English in the English Language Teaching classroom: from second language learners' perspectives. Innovation in Language Learning and Teaching, 10(3), 190-205. 